\title{
The role of science education in skills acquisition and youth empowerment in Nigeria
}

\author{
Adolphus, $\mathrm{T}$. \\ Department of Science Education, \\ Faculty of Education \\ Rivers State University \\ Nkpolu-Oroworukwo, Port Harcourt, Nigeria. \\ Email: adolphus.telima@ust.edu.ng.
}

\begin{abstract}
The paper focuses on the roles of science education in youth empowerment in Nigeria. Nigeria in recent times has been plagued with cases of youth restiveness and vices that has defied several approaches by successive governments to curb. This paper discussed the philosophy of education in Nigeria to highlight the roles of education in the inculcation of right values, knowledge and skills in young people to enable them contribute effectively to national development. Particularly, the paper discussed the $21^{\text {st }}$ century skills needed for effective youth empowerment, role of science education in skills acquisition and youth empowerment, and strategies for enhancing youth empowerment through science education. The paper concluded with some recommendations for the effective employment of science education for youth empowerment in Nigeria.
\end{abstract}

Key words: Science Education, $21^{\text {st }}$ century skills, Scientific Literacy, Youth empowerment

\section{Introduction}

There are many cases of youth restiveness in every region of Nigeria. These cases include militancy kidnapping, oil bunkering, Herdsmen/farmers clashes, murderous acts by Boko Haram religious extremists and armed robbery. Most of the key players in all these are youths who are either unemployed or under-employed. Some of them are graduates with no relevant skills for entrepreneurial adventures. Since 2014, Nigeria's Unemployment rate has been rising steadily from $6.4 \%$ in 2014 to $23.13 \%$ in 2018 with $20.1 \%$ underemployment rate (Nigeria Bureau of Statistics, 2020). The implication of all these is a great burden on the government, parents and communities to curb the challenge of insecurity and frustration posed by these youths. Education and particularly science education are geared towards the inculcation of the right values, knowledge and skills in the young populace of any nation to enable them fit in and responsibly contribute to the development of their communities and nations. This view is consistent with the beliefs of the Nigeria's philosophy of education as enunciated in the National Policy of Education (FRN, 2013): 
i. Education is an instrument for national development and social change

ii. Education is vital for the promotion of a progressive and united Nigeria

iii. Education maximizes the creative potentials and skills of the individual for selffulfilment and general development of the society (p.1).

The beliefs of the philosophy of education in Nigeria are consistent with the general goals of science education. According to Harlen et al (2015), Science is the ideas about the natural world, warranted by empirical evidence, that have been accumulated over time and the processes by which these ideas have been generated. Science education involves the training of future scientists and teachers who would be equipped with the relevant skills and knowledge to effectively function in work places and or to appropriately communicate the principles and applications of science to learners at different levels.

Generally in literature, the challenge of the effective teaching and learning of school science subjects like physics, chemistry and biology has been attributed to the nature of the subject that appears to have a high difficulty perception, shortage of qualified teachers, inadequate teaching facilities and irrelevance of some of the content to the everyday experience of the learners (FME, 2009c; Angell, et al., 2004). These challenges of teaching and learning of science in schools in Nigeria, particularly in public schools with inadequate supply of science teachers, lack of adequately equipped science laboratories for teaching and learning and training needs of science teachers have been sufficiently reported in literature (see for instance, Adolphus, 2016; Adeyemi, 2008; Bello, 2012). It is therefore important that schools be positioned in good form to effectively deliver on its goals in actualising the desired objectives of 'maximizing the creative potentials and skills of the individual for self-fulfilment and general development of the society'. There are very important skills that youths must possess to get them empowered so as to function effectively and productively in the $21^{\text {st }}$ century economy.

This paper focusses on the $21^{\text {st }}$ century skills needed for effective youth empowerment, role of science education in youth empowerment and strategies for enhancing youth empowerment through science education.

\section{The philosophy of education in Nigeria}

The philosophy of education in Nigeria is captured in the National policy on Education. The policy articulates the guidelines, objectives, teaching and learning standards, structures for the implementation of government policy on education, strategies and management for achieving the national education goals in Nigeria. The general philosophy of Nigeria from where the philosophy of education is derived includes: 
i. live in unity and harmony as one indivisible, indissoluble, democratic and sovereign nation founded on the principles of freedom, equality and justice; and

ii. promote inter-African solidarity and world peace through understanding (FRN, 2013:1) These postulations as philosophy though lofty, appears vague as most of the variables such as unity, harmony, freedom, equality, justice, solidarity and peace are relatively subjective. However, the philosophy of Nigeria aligns with the five main national goals as stated in the National Policy on Education (FRN, 2013:1) is the building of:

i. a free and democratic society,

ii. a just and egalitarian society,

iii. united, strong and self-reliant nation,

iv. a great and dynamic economy, and

v. a land full of bright opportunities for all citizens.

The role of education in any nation is the actualisation of the general goals of education for the nation. As highlighted above, the Nigeria's philosophy of education is based on the belief that education is an instrument for national development and social change. This is also consistent with the subjectification, socialisation and qualification domains of the purposes of education as posited by Biesta (2015).

\section{$21^{\text {st }}$ century skills for effective youth empowerment in Nigeria}

The phrase $21^{\text {st }}$ century skills refers to a broad set of knowledge, skills, work habits, and character traits that are believed by stake holders such as teachers, policy makers, researchers, employers of labour, and others to be critically important to success in today's world. They argue that the current century will demand a very different set of skills and competencies from products of learning establishments in order for them to function effectively at work, as citizens and in their leisure time (Ananiadou \& Claro, 2009).

Skills and competencies are sometimes used interchangeably. The two terms have some relationships, although there are some distinctions between them. The European Centre for the Development of Vocational Training, (CEDEFOP, 2008) defines a skill as the ability to perform tasks and solve problems, while a competence is the ability to apply learning outcomes adequately in a defined context of work, education or professional development. Competence goes beyond cognitive elements that involve the use of theory, concepts or tacit knowledge to cover functional aspects that involve technical skills, and interpersonal attributes such as social or organizational skills and ethical values. For example, the ability to communicate effectively is a competence that may draw on an individual's knowledge of language, practical information 
technology skills and attitudes towards those with whom they communicate (Rychen \& Salganik, 2003).

Specific skills deemed to be ' $21^{\text {st }}$ century skills' may vary from person to person, or mean differently from place to place. However, there appears to be some consensus in literature about what the term generally reflects (see for instance, Holbrook \& Rannikmae, 2009; Ananiadou, \& Claro, 2009; Maienschein, 1998). The following list, though not exhaustive, provides some descriptions of knowledge, character traits, and skills that are generally referred to as $21^{\text {st }}$ century skills: Information and communication technology (ICT) literacy, critical thinking, problem solving, reasoning, analysis, synthesizing information, research skills and practices, creativity, artistry, curiosity, imagination, innovation, perseverance, self-direction, planning, self-discipline, adaptability, initiative, oral and written communication, leadership, teamwork, and collaboration.

\section{The role of science education in youth empowerment in Nigeria}

Science education involves the training of future scientists and teachers who would be equipped with relevant skills and knowledge to effectively communicate the principles and applications of science to learners. Science education could also involve the enlightenment of the populace on the usefulness of science and its applications to the everyday life of individuals. The later may be referred to as scientific literacy. Scientific literacy is the knowledge and understanding of scientific concepts and processes required for personal decision making, participation in civic and cultural affairs, and economic productivity. It also includes specific types of abilities. The Organisation of Economic Cooperation and Development (OECD, 2009) defined scientific literacy as an individual's scientific knowledge and use of that knowledge to identify questions, to acquire new knowledge, to explain scientific phenomena, and to draw evidence-based conclusions about science-related issues, understanding of the characteristic features of science as a form of human knowledge and enquiry, awareness of how science and technology shape our material, intellectual, and cultural environments, and willingness to engage in science-related issues, and with the ideas of science, as a reflective citizen. Science literacy provides a context for addressing societal problems. A science-literate populace can better cope with many of its problems and make intelligent and informed decisions that will affect the quality of their lives and those of their children (Zen, 1990).

Science is taught is schools in Nigeria as Basic Science and Technology in Primary and Junior secondary school level and as Biology, Chemistry and physics as basic science subjects at the senior secondary school level. 
The purposes of science education in Nigeria are generally drawn from the national goals and philosophy of education as contained in the National Policy on Education (NPE). For instance, the goals of education in Nigeria include:

Development of the individual into a morally sound, patriotic and effective citizen; ... and social abilities and competencies as equipment for the individual to live in and contribute to the development of the society (FRN 2013, p.2).

According to the national policy text, the goals of science education shall be to:

(i) Cultivate inquiring, knowing and rational mind for the conduct of a good life and democracy

(ii) Produce scientist for national development

(iii) Service studies in technology and the cause of technological development; and

(iv) Provide knowledge and understanding of the complexity of the physical world, the forms and the conduct of life. (FRN 2004, p.29).

These goals appear very lofty, but vague (Adolphus, 2019). For instance, what defines moral soundness when morality is itself 'indefinable' (Skorupski 1993, p.121), and is subject to social and cultural interpretations? In addition, what criteria are set to identify an 'effective citizen'? What is the parameter to measure one who has cultivated an 'inquiring, knowing and rational mind'? In addition, what does - 'for the conduct of a 'good life' and democracy' mean? These are clearly subject to different interpretations by the end users of the policy.

The science subject curricula also derived their specific objectives from the NPE national and science education goals. For instance, the objectives of the Basic Science and Technology (BST) curriculum for the first 9 years of school are to enable learners to:

Develop interest in science and technology, acquire basic knowledge and skills in science and technology, apply their scientific and technological knowledge and skills to meet societal needs, take advantage of the numerous career opportunities offered by science and technology, become prepared for further studies in science and technology, avoid drug abuse and related vices, and be safety and security conscious (FME 2012, p. vii).

Similarly, the objectives of the biology curriculum for senior secondary schools are to prepare students to acquire: 
Adequate laboratory and field skills in biology, meaningful and relevant knowledge in biology, ability to apply scientific knowledge to everyday life in matters of personal and community health and agriculture, and reasonable and functional scientific attitude (FME 2009a, p. iii).

Some of the objectives of the chemistry curriculum are to enable students to:

Develop interest in the subject of chemistry, in science, technology and mathematics, acquire basic theoretical and practical knowledge and skills, and develop reasonable level of competence in ICT applications that will engender entrepreneurial skills and apply skills to meet societal needs of creating employment and wealth (FME 2009b, p. iv).

While the general objectives of the physics curriculum is to:

Provide basic literacy in physics for functional living in the society, (enable learners to) acquire basic concepts and principles of physics as a preparation for further studies, acquire essential scientific skills and attitudes as a preparation for technological application of physics, and (to) stimulate and enhance creativity (FME 2009c, p. ii).

Although the some of the specific science curricula objectives can be argued to be vague, just as the national goals of science education, it is nonetheless possible to align the subject curricula objectives with the national goals. These goals and objectives of science education demonstrate government's intention to equip and empower young people with scientific knowledge and skills to participate productively, contribute to the growth of society and to occupy positions in science and technology related fields that drive the global economy. Science education is the acquisition of knowledge about the structure and behaviour of the natural and physical word (Oloyede, 2007), and is very important to the development of any nation (Omosewo, 2009).

\section{Youth empowerment and the way forward through science education}

From the foregoing, the philosophies of general education and science education in particular are consistent and demonstrate governments' intention to drive youth empowerment through education. However, evidence in literature suggests that the sorry state of science teaching and learning resources in Nigeria and the didactic approach used by most science teachers (see for instance, Adolphus, 2019; Zhu, 2008; Williams, et, al., 2003) have hindered the actualisation of the goals of science education in empowering youths with appropriate skills that could enable them to contribute meaningfully to the development of the country. For instance, there are good topics in physics, such as electric field, application of electrolysis, $\underset{w w w . i j r p . o r g}{\text { capars }}$ 
capacitance and their applications, electromagnetic induction, Physics in Technology - repairs and maintenance of machines that when properly taught with adequate teaching and learning resources could enable young people to acquire skills and knowledge that are relevant for entrepreneurial endeavours. Also, students studying Chemistry could be exposed to skills and knowledge in the making of dye, chalk, soap, perfume, hand sanitizers and other useful cleaning chemicals if the curriculum is well planned. It is likely that youths with skills and knowledge who are entrepreneurs may not have reasonable attraction towards restive destructive tendencies such as cultism, kidnapping, armed robbery and other harmful practices (Awogbenle \& Iwuamadi, 2010; Ofem \& Ajayi, 2008).

\section{Strategies for enhancing youth empowerment through science education}

Many stakeholders in the teaching and learning of young people in science across all levels are concerned about the effectiveness of the teaching with learners acquiring desired skills and knowledge (see Harlen, et al.,2015). Studies have shown that many students veer away from science after the compulsory years of schooling as a result of their experiences and how science, particularly the physical sciences are presented to them - generally in dry and abstract forms (Adolphus, 2016; Samela, 2010; Omosewo, 2003; Williams, et al., 2003). Some strategies that have been effective in supporting learners in the achievement learning goals include

i. Interactive and constructivist teaching practices with safe and supportive (Adolphus, 2019; Alamina \& Etokeren, 2018)

ii. More pedagogical resources, greater teacher training and content knowledge, and better science teaching and learning school facilities (Masino \& Nino-Zarazua, 2016; Bolton, 2018)

iii. $\quad$ Feedback, sustained attention and inclusion (Bolton, 2018)

iv. Positive teacher attitudes towards their training and their students (Westbrook, et al., 2013).

v. Monitoring, inspections and assessments with consistent and clear feedback about outcomes (Eddy-Spicer, et al., 2016).

\section{Conclusion}

This review has far-reaching implications on the perspectives of teacher educators, teachers, students, school administrators, parents, civic sectors and community stakeholders. Institutions that are accredited for the training and production of teachers need to overhaul their curricula to include a focus skills acquisition, entrepreneurship and youth empowerment. This will enable the trainee or student teachers to acquire the necessary knowledge and skills to effectively guide students during and after their training at the primary and secondary schools' level towards youth empowerment and skills acquisition. School administrators, government and other funding agencies also have the responsibility to encourage the actualisation of youth empowerment by providing adequate and up-to-date teaching and learning facilities that are necessary to meet the $21^{\text {st }}$ century learning needs of young people. Parents also have a role to play in supporting both the school and government efforts at home and in the provision of working materials as may be required. 
Effective science classroom experiences, where science teachers that are adequately trained with appropriate knowledge and skills are engaged in the teaching of young people in Nigeria, could be a veritable tool to curb the cases of youth restiveness. Youths can be empowered with useful $21^{\text {st }}$ century skills such as creativity, ICT literacy, critical thinking and problem solving through science lessons in basic science and technology, biology, chemistry and physics to contribute meaningfully to the society and to occupy their right place in an ICT driven economy.

\section{Recommendations}

In view of the relevance of science education in the empowerment of youths with skill and knowledge as evident in the body of literature reviewed, it is recommended that

1. Science teachers employ more learner-centred and interactive strategies in science teaching and learning right the basic education levels in Nigeria.

2. That government invest in the proper training of science teachers and in the provision of sufficient teaching and learning science resources, such as adequately resourced laboratories for the effective teaching and learning of science in schools.

3. Teachers provide adequate and timely feedback of learning outcomes to learners with inclusion of all learners without prejudice.

4. Science teachers should demonstrate positive attitudes towards their training and to their students

5. Effective monitoring, inspections and assessments with consistent and clear feedback about outcomes should be carried out by supervising agencies.

\section{References}

Adeyemi, T. O. (2008). Science laboratories and the quality of output from secondary schools in Ondo State, Nigeria. Asian Journal of Information Management, 2(1),23-30.

Adolphus, T. (2019). Why students in secondary schools choose not to do physics? Implications for policy and practice in developing countries. European Scientific Journal, 15(34), 103-124.

Adolphus, T. (2019). The aims and purposes of science education: socio-scientific issues in the science curriculum in Nigeria. American Research Journal of Humanities \& Social Science, 2(7), 21-29.

Alamina, J., \& Etokeren, I.S. (2018). Effectiveness of Imagination Stretch Teaching Strategy in Correcting Misconceptions of Students about Particulate Nature of Matter, Journal of Education, Society and Behavioural science, 27(1), 1-11.

Ananiadou, K. \& Claro, M. (2009), "21st Century Skills and Competences for New Millennium Learners in OECD Countries", OECD Education Working Papers, No.

41, OECD Publishing. http://dx.doi.org/10.1787/218525261154.

Angell, C., Guttersrud, O., Henriksen, E.K. \& Isnes, A. (2004). Physics: Frightful, But Fun Pupils' and Teachers' Views of Physics and Physics Teaching. Science education, 88(5), 683-706.

Awogbenle, A. C., \& Iwuamadi, K. C. (2010). Youth unemployment: Entrepreneurship development programme as an intervention mechanism. African Journal of Business Management, 4(6), 831-835.

Bello, T. O. (2012). Effect of Availability and Utilization of Physics Laboratory Equipment on Students' Academic Achievement in Senior Secondary School Physics. World Journal of Education, 2(5), 1-7.

Biesta, G. (2015). What is education for? On good education, teacher judgement and educational professionalism, European Journal of Education, 50(1), 75-87. 
Bolton, L. (2018). Effective learning strategies to improve basic education outcome, K4D Helpdesk Report. Brighton, UK

CEDEFOP (2008) Terminology of European education and training policy. A selection of 100 key terms. Luxembourg: Office for Official Publications of the European Communities. Retrieved online from www. Cedefop.europa.eu.

Eddy-Spicer, D., Ehren, M., Bangpan, M., Khatwa, M. \& Perrone, F. (2016). Under what conditions do inspection, monitoring and assessment improve system efficiency, service delivery and learning outcomes for the poorest and most marginalised? A realist synthesis of school accountability in low- and middle-income countries. London: EPPICentre, Social Science Research Unit, UCL Institute of Education, University College London.

Federal Ministry of Education, FME (2009a). National biology curriculum for senior secondary schools: Abuja: Nigerian Educational Research and Development Council.

Federal Ministry of Education, FME (2009b). National chemistry curriculum for senior secondary schools: Abuja: Nigerian Educational Research and Development Council.

Federal Ministry of Education, FME (2009c). National physics curriculum for senior secondary schools: Abuja: Nigerian Educational Research and Development Council.

Federal Ministry of Education, FME (2012). The Basic Science and Technology Curriculum: Abuja: Nigerian Educational Research and Development Council.

Federal Republic of Nigeria (FRN) (2013). National Policy on Education, $6^{\text {th }}$ edition: Lagos: NERDC press.

Maienschein, J. (1998). Scientific Literacy, Science, 281(5379), 917.

Harlen, W., Bell, D., Deves, R., Dyasi, H., de la Garza, G.F., Lena, P., Millar, R., Reiss, M., Rowell, P. \& Yu, W. (2015) Working with big ideas of science education. Trieste, Italy: Science Education Programme (SEP) of IAP.Rychen \& Salganik, 2003.

Holbrook, J. \& Rannikmae, M. (2009). The Meaning of Scientific Literacy, International Journal of Environmental \& Science Education, 4(3), 275-288.

Masino, S. \& Nino-Zarazua, M. (2016). What works to improve the quality of student learning in developing countries, International Journal of Educational Development, 48, 53-65

Nigeria Bureau of Statistics (2020). Key Statistics: Unemployment and underemployment rates in Nigeria. Retrieved online from www.nigerianstat.gov.ng

Ofem, N.I. \& Ajayi, A.R. (2008). Effects of youth empowerment strategies on conflict resolutions in the Niger Delta of Nigeria: Evidence from Cross River State, Journal of Agriculture \& Rural Development, 6(1), 139-146.

Oloyede, E. O. (2007). Science education and technological development in Nigeria. International Journal of Research in Education, 4 (1\&2),95-103.

Omosewo, E.O. (2003). Factors influencing Female Students' choice of Physics in Selected Secondary Schools in Ilorin Metropolis. Journal of Studies in Education, 1(5), 131 140.

Omosewo, E. O. (2009). Views of physics teachers on the need to train and retrain physics teachers in Nigeria, African Research Review, 3 (1),314-325, 2009.

Organisation for Economic Cooperation and Development (2009). PISA 2009 Assessment Framework. Key competencies in reading, mathematics and science. Paris: OECD.

Osborne, J., Simon, S. \& Collins, S. (2003). Attitudes towards science: a review of the literature and its implications. International Journal of Science Education, 25(9), 1049-1079.

Reid, N. \& Skryabina, E. A. (2002). Attitudes towards Physics. Research in Science \& Technological Education, 20(1), 67-81.

Semela, T. (2010). Who is joining physics and why? Factors influencing the choice of 
physics among Ethiopian university students. International Journal of Environmental \& Science Education. 5(3), 319 - 340.

Skorupski, J. (1993). The definition of Morality, Royal Institute of Philosophy Supplement, 35, 121-144.

Smithers, A. \& Robinson, P. (2009). Physics Participation and Policies: Lessons from Abroad Buckingham: Carmichael Press.

Wasanga, C. M. (1997). The attitude towards science among primary and secondary school students in Kenya. Nairobi: Academy of science publishers.

Westbrook, J., Durrani, N., Brown, R., Orr, D. Pryor, J., Boddy, J. \& Salvi, F. (2013). Pedagogy, curriculum, teaching practices and teacher education in developing countries, Final Report. Education Rigorous Literature Review. Department for international Development. Retrieved online from http://r4d.dfid.gov.uk.

Williams, C., Stanisstreet, M., Spall, K., Boyes, E.\& Dickson, D. (2003). Why aren't secondary students interested in physics? Physics Education, 38(4), 324 - 329.

Zen, E. (1990). Science Literacy and why it is important, Journal of Geological Education, 38(5), 463-464.

Zhu, Z. (2008). A Comparison Study of Students' Reasons for Taking Physics between Two Australian High Schools and Two Chinese High Schools. Paper presented at the Australian Association for Research in Education held at Brisbane. 